\title{
Polymorphonuclear granulocytes in rheumatic tissue destruction. III. An electron microscopic study of PMNs at the pannus-cartilage junction in rheumatoid arthritis
}

\author{
W. MOHR, H. WESTERHELLWEG, AND D. WESSINGHAGE \\ From the Department of Pathology, University of Ulm, and the Centre of Rheumatology, Bad Abbach, West \\ Germany
}

SUMMARY Metatarsophalangeal and metacarpophalangeal joints from 3 patients with rheumatoid arthritis were investigated electron microscopically with regard to the occurrence of polymorphonuclear granulocytes (PMNs) at the pannus-cartilage junction. In all 3 cases PMNs could be detected at the junction and within the cartilaginous matrix. PMN cytoplasmic processes surrounded collagenous islands in the cartilage. From the morphological findings it is deduced that PMNs are cells capable of destroying cartilage in inflammatory joint diseases, in particular in rheumatoid arthritis.

Using enzyme histochemical and immune histological investigations we recently demonstrated the appearance of polymorphonuclear granulocytes (PMNs) at the pannus-cartilage junction in rheumatoid joints. ${ }^{1-4}$ As some doubt remains about the specificity of the naphthol-AS-D-chloroacetate esterase reaction ${ }^{5}$ for the demonstration of PMNs with regard to the content of this enzyme in monocytes, ${ }^{6}$ we tried to characterise PMNs at the pannuscartilage junction by electron microscopy.

\section{Material and methods}

Surgically removed metatarsophalangeal and metacarpophalangeal joints were fixed in buffered formalin. After decalcification in Versen (Titriplex III) the specimens were bisected. One half of the tissue was processed by the routine paraffin method, stained with haematoxylin-eosin and the naphtholAS-D-chloroacetate esterase reaction. ${ }^{5}$ The second half was stored in formalin. Joints from 3 patients (Table 1) with accumulations of PMNs at the pannuscartilage junction, proved by light microscopy, were chosen for electron microscopy. From areas corresponding to the histological PMN-rich foci small pieces of the articular cartilage with adherent pannus tissue were dissected and rinsed in water. Thereafter

Accepted for publication 7 October 1980.

Correspondence to Professor W. Mohr, Abteilung Pathologie, Universität Ulm, 7900 Ulm, Eselsberg, West Germany.
Table 1 Summary of the clinical data of the patients

\begin{tabular}{llllll}
\hline Case no. & Sex & $\begin{array}{l}\text { Age } \\
\text { (years) }\end{array}$ & $\begin{array}{l}\text { Clinical } \\
\text { diagnosis }\end{array}$ & $\begin{array}{l}\text { Duration Joint } \\
\text { of disease } \\
\text { (years) }\end{array}$ & \\
\hline E 16951/78 & f & 61 & RA & 16 & Metatarsophalangeal \\
E 8528/79 & m & 60 & RA & 36 & Metacarpophalangeal \\
E 20266/79 & f & 60 & RA & 8 & Metatarsophalangeal \\
\hline
\end{tabular}

they were postfixed in osmic acid, dehydrated, and embedded in Araldite. Semithin sections were prepared with a Reichert Ultramicrotome OMU 3 and stained with toluidine blue. The ultrathin sections were stained with uranyl acetate and lead citrate. The sections were examined with a Zeiss EM 10 electron microscope.

\section{Results}

Even in the formalin prefixed tissue ultrastructural details of the cartilaginous matrix and the cells were remarkably well preserved. Vacuoles in pannus tissue cells may be due to this fixation process.

PMNs identified by their condensed nuclear chromatin, electron-dense cytoplasmic granules, intracytoplasmic lipid droplets, and the absence of rough endoplasmic reticulum were found in each of the 3 patients. These inflammatory cells were rarely present in the pannus tissue outside the cartilage. However, they often appeared in the immediate vicinity of the cartilage in the pannus-cartilage 


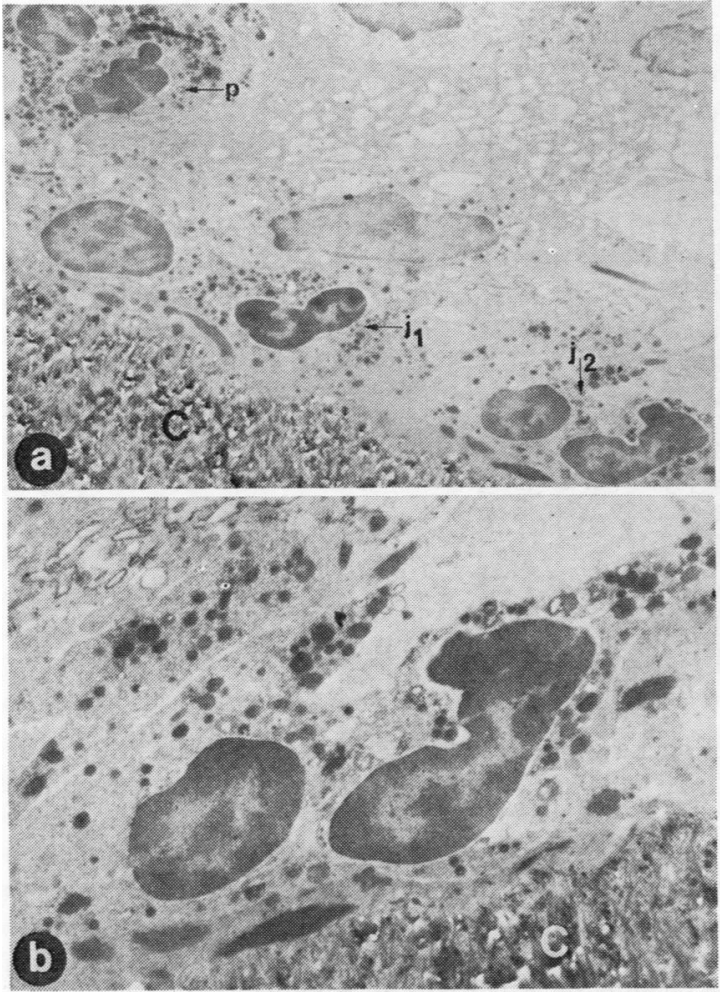

Fig. 1 PMNs at the pannus-cartilage junction. (a) PMN (p) in the pannus tissue in the neighbourhood of the cartilage $(C)$ and PMNs $\left(\mathrm{j}_{1}\right.$ and $\left.\mathrm{j}_{2}\right)$ in the immediate vicinity of the cartilage. $(\times 2700)$. (b) Higher magnification of the PMN $\left(\mathrm{j}_{2}\right)$. Cytoplasm of the inflammatory cell with electron-dense granules in direct contact with the cartilage $(\mathrm{C}) .(\times 6750)$.

junction (Fig. 1). In some areas PMNs had invaded deep into the cartilage matrix, surrounded by the collagenous fibres of the cartilage. Some inflammatory cells were even observed in chondrocytic lacunae with remnants of chondrocytes (Fig. 2). In most instances the PMNs were surrounded by a distinctive cellular membrane. Cytoplasmic processes of these inflammatory cells extended deep into the cartilaginous matrix. Islands of collagenous fibres were separated by the cytoplasmic processes from the adjacent cartilage (Fig. 3). The collagenous fibres usually showed a preserved periodicity. However, in some instances small fibres without obvious periodicity were present in the neighbourhood of the PMNs.

\section{Discussion}

In the inflammatory destruction of cartilage proteoglycans and collagenous fibres are destroyed.

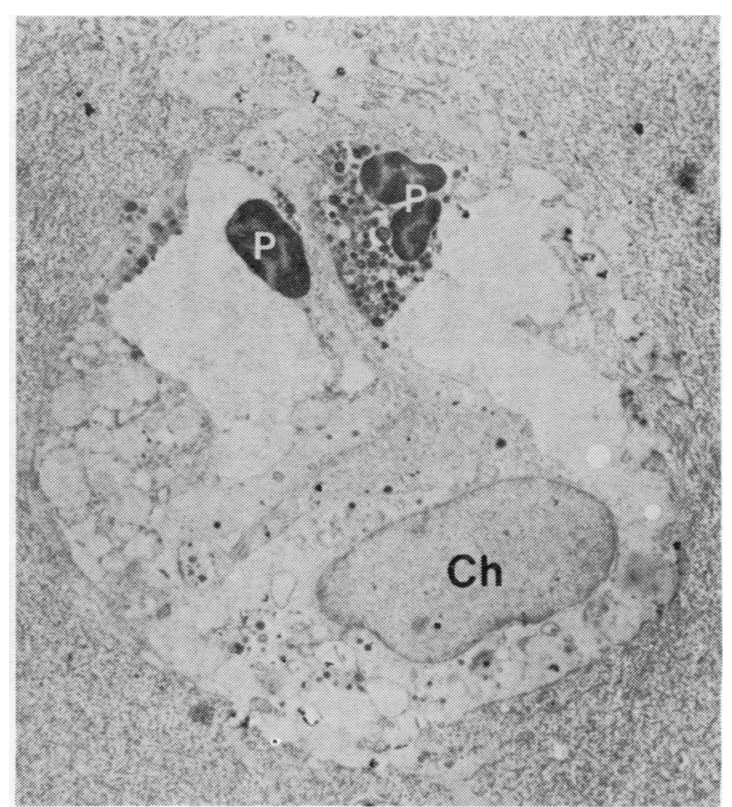

Fig. 2 Two PMNs $(\mathrm{P}=$ condensed nuclei $)$ in a chondrocytic lacuna with remnants of the chondrocyte $(C h=$ nucleus of the chondrocyte $) .(\times 3580)$.

Enzymes of mononuclear inflammatory cells ${ }^{7}$ and of synoviocytes $^{7-11}$ are usually regarded as the most important destructive agents. However, there is some evidence that chondrocytes themselves may be involved in cartilage degradation. ${ }^{12-16}$

The participation of PMNs in rheumatic tissue destruction is usually neglected. According to Hadler et al. ${ }^{17}$ there is no positive correlation between the activity of lysosomal enzymes in the synovial fluid and the degree of cartilage destruction. Moreover it is said that PMNs are absent at the pannuscartilage junction. ${ }^{8}$ 18-21

In contrast to the results of the morphological investigations quoted above Mohr and Wessinghage $^{1}$ demonstrated the presence of PMNs at the pannus-cartilage border by a histochemical study. Moreover by the combination of histochemical and immunohistological methods PMNs were detected at the pannus-cartilage junction. ${ }^{2-4} 22$

The present ultrastructural investigation confirms these previous results. By electron microscopy PMNs were observed as isolated cells attached to the cartilage or invading the cartilaginous matrix and even chrondrocytic lacunae. In some areas PMNs were seen accumulating at the pannus-cartilage border as described by Ugai et al..$^{24}$ in their in-vitro experiments using the incubation of cartilage (from BSAinjected joints of immunised rabbits) with PMNs. 


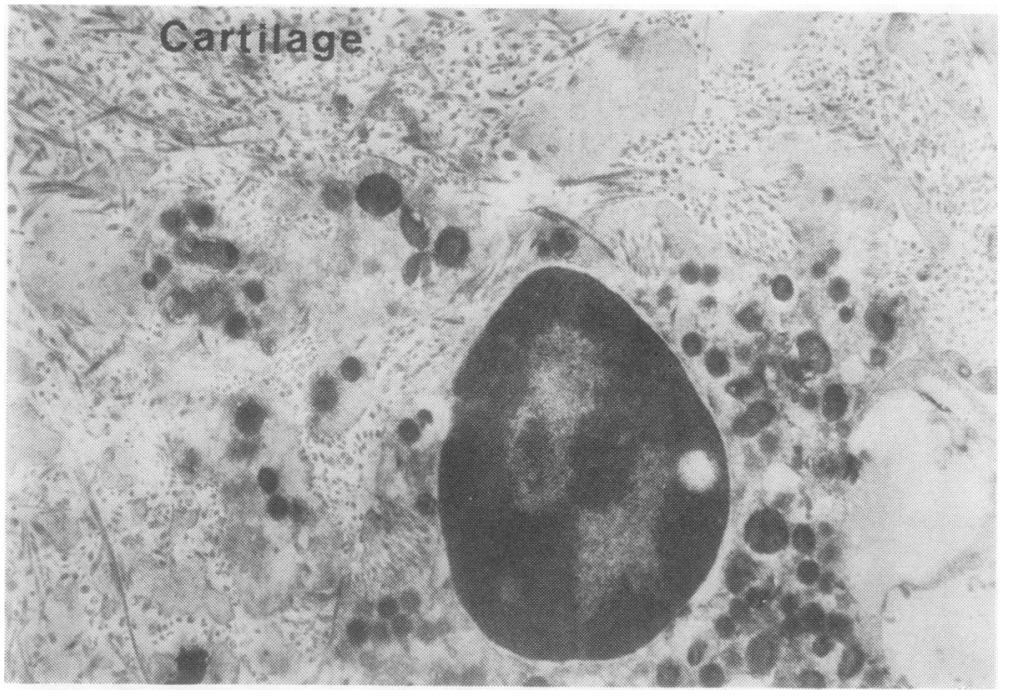

Fig. 3 Relationship between the collagenous fibres of the cartilage and the cytoplasm of a PMN: cytoplasmic processes of the $P M N$ extending into the cartilaginous matrix. $(\times 14000)$.

The infiltration of the cartilage by PMNs is by no means unknown. It has been reported in human septic arthritis ${ }^{24-27}$ and is also found in experimental adjuvant arthritis in the rat. ${ }^{28} 29$

However, the morphological relationship between these inflammatory cells and cartilage does not necessarily mean the participation of these cells in cartilage destruction. Nevertheless, this localisation of the inflammatory cells may be regarded as a possible way by which enzymes of PMNs, capable of degrading proteoglycans ${ }^{30-34}$ and collagenous fibres, ${ }^{34}{ }^{35}$ may attack cartilage in a microenvironment in the absence of serum inhibitors.

The stimulus responsible for the localisation of PMNs at the pannus-cartilage junction remains obscure. Ugai et al. ${ }^{23}$ observed the invasion by PMNs of cartilage pretreated with immune complexes under in-vitro conditions. Whether such a chemotactic mechanism is at work in rheumatoid arthritis is unknown. Moreover, it is possible that cartilage merely acts as a mechanical barrier, thus inhibiting the random migration of PMNs in pannus, resulting in the accumulation of these inflammatory cells at the borderline of the cartilage barrier. ${ }^{36}$ Bacterial remnants were not observed in the present study. However, further investigations should be made to ensure that the described phenomenon is not due to an infectious agent. A surgically induced infiltration of the pannus tissue may be excluded: vascular margination of PMNs was usually absent in the area of accumulation of the inflammatory cells at the pannus-cartilage junction. Intra-articular injections were not performed in these patients during the preoperative period. Finally, it should be mentioned that the presence of PMNs in fibrinoid necrosis of rheumatoid nodules ${ }^{37}{ }^{38}$ also favours the idea that these cells are involved in rheumatic tissue destruction.

It is not the aim of this paper to explain inflammatory destruction of cartilage purely on the basis of granulocytic enzymes. From investigations in recent years it has been learned that other cells (monocytes, ${ }^{7}$ the dendritic cell, ${ }^{3940}$ and synoviocytes, ${ }^{781011}$ ) are also involved. It therefore appears that inflammatory destruction of cartilage in the rheumatoid joint is probably an enzymatic process due to several kind of cells: it is not a process attributable solely to mononuclear macrophages.

The investigations were supported by a grant from the Deutsche Forschungsgemeinschaft (Mo 183/6).

The capable technical help of Mrs R. Endres-Klein and Miss B. Blell is gratefully acknowledged.

\section{References}

1 Mohr W, Wessinghage D. The relationship between polymorphonuclear granulocytes and cartilage destruction in rheumatoid arthritis. $Z$ Rheumatol $1978 ; 37: 81-6$.

2 Mohr W, Menninger H, Putzier R. Morphologische Hinweise für die Beteiligung neutrophiler Granulozyten an der rheumatischen Knorpeldestruktion. Bull Schweiz Akad Med Wiss 1979; 35 : 443-51.

3 Menninger H, Putzier R, Mohr W, Hering B, Mierau H D. Role of granulocyte elastase in rheumatoid arthritis: effect on mechanical behavior of cartilage and identification at the cartilage/pannus junction. 30. Colloq. Ges. Biochem. In: Holzer $\mathbf{H}$, Tschesche $\mathrm{H}$, eds. Biological Functions of Proteinases. Berlin-Heidelberg: Springer, 1979; 196-206.

4 Menninger $\mathbf{H}$, Putzier $\mathbf{R}$, Mohr W, Wessinghage $D$, Tillmann K. Granulocyte elastase at the sites of cartilage erosion by rheumatoid synovial tissue. $Z$ Rheumatol 1980 ; 39: 145-56. 
5 Leder L D. Der Blutmonozyt. Berlin-Heidelberg-New York: Springer, 1967.

6 Meuret G. Monozytenpoese und Klinik der Blutmonozyten beim Menschen. Blut 1972; 24 : 337-45.

7 Vaes G, Hauser P, Huybrecht-Godin G, Peeters-Joris C. Cartilage degradation by macrophages, fibroblasts and synovial cells in culture. An in vitro model suitable for studies on rheumatoid arthritis. In: Willoughby D A, Giroud J P, Velo G P, eds. Perspectives in Inflammation. Lancaster: MTP Press, 1977; 115-26.

8 Harris E D, Faulkner C S, Brown F E. Collagenolytic systems in rheumatoid arthritis. Clin Orthop 1975; 110: 303-16.

- Harris E D, Mainardi C L, Werb Z. Collagenolysis in rheumatoid arthritis. In: Gordon J L, Hazleman B L, eds. Rheumatoid Arthritis. Amsterdam: Elsevier/NorthHolland Biomedical Press, 1977: 199-209.

10 Dayer J-M, Russell R G G, Krane S M. Collagenase production by rheumatoid synovial cells: stimulation by a human lymphocyte factor. Science $1977 ; 195$ : 181-3.

11 Muirden K D, Rogers K. Electron microscopy and synovial pathology. Aust NZ J Med 1978; 8 (Suppl 1): 20-2.

12 Deshmukh-Phadke K, Lawrence M, Nanda S. Synthesis of collagenase and neutral proteases by articular chondrocytes: stimulation by a macrophage-derived factor. Biochem Biophys Res Comm 1978; 85: 490-6.

13 Dingle J T. Articular damage in arthritis and its control. Ann Intern Med 1978; 88: 821-6.

14 Dingle J T. Recent studies on the control of joint damage: the contribution of the Strangeways Research Laboratory. Ann Rheum Dis 1979; 38: 201-14.

15 Malemud C J, Weitzman G A, Norby D P, Sapolsky A I, Howell D S. Metal-dependant neutral proteoglycanase activity from monolayer-cultured lapine articular chondrocytes. J Lab Clin Med 1979; 93: 1018-30.

16 Ridge S C, Oronsky A L, Kerwar S S. Induction of the synthesis of latent collagenase and latent protease in chondrocytes by a factor synthesized by activated macrophages. Arthritis Rheum 1980; 23: 448-54.

17 Hadler N M, Spitznagel J K, Quinet R J. Lysosomal enzymes in inflammatory synovial effusions. $J$ Immunol 1979; 123: 572-7.

18 Harris E D, Dibona D R, Krane S M. Mechanisms of destruction of articular structures in rheumatoid arthritis. In: Immunpathology of Inflammation. Excerpta Medica International Congress Series 1970; 229 : 243-53.

19 Krane S M. Collagenase production by human synovial tissues. Ann N Y Acad Sci 1975; 256: 289-303.

20 Barrett $\mathrm{A} \mathrm{J}$. The possible role of neutrophil proteinases in damage to articular cartilage. Agents Actions 1978; 8: 11-7.

21 Woolley D E, Crossley M J, Evanson J M. Collagenase at sites of cartilage erosion in the rheumatoid joint. Arthritis Rheum 1977; 20: 1231-9.

22 Mohr W. Zur Pathogenese der entzündlichen Knorpelzerstörung bei der chronischen Polyarthritis. Dtsch Med Wochenschr 1980; 105: 868-72.

23 Ugai K, Ziff M, Jasin H E. Interaction of polymorphonuclear leukocytes with immun complexes trapped in joint collagenous tissues. Arthritis Rheum 1979; 22: 353-64.
24 Ziegler E. Lehrbuch der allgemeinen Pathologie und pathologischen Anatomie. 11 ed. Jena: Gustav Fischer, 1906: 2.

25 Axhausen G. Über die Wundgestaltung bei Operationen an den Rippenknorpeln. Arch Klin Chir 1912; 29: 219-42.

${ }^{26}$ Chiari H. Die eitrigen Gelenkentzündungen. In: Lubarsch O, Henke F. Handbuch der speziellen pathologischen Anatomie und Histologie, IX/2 Gelenke und Knochen. Berlin: Springer, 1934: 12-74.

27 Mohr W, Wessinghage D. Knorpelzerstörung im bakteriell superinfizierten Gelenk. Aktuel Rheumatol $1980 ; 5: 157-62$.

${ }^{28}$ Mohr W, Wild A, Wolf H P. Role of polymorphs in inflammatory cartilage destruction in adjuvant arthritis of the rat. Ann Rheum Dis in press.

29 Mohr W, Wild A, Wolf H P. Untersuchungen zur Pathogenese der entzündlichen Knorpelzerstörung bei der Adjuvansarthritis der Ratte. $Z$ Rheumatol 1980; 39: 212-22.

30 Ziff M. Gribetz H J, Lospalluto J, Effect of leucocyte and synovial membrane extracts on cartilage mucoprotein. J Clin Invest $1960 ; 39$ : 405-12.

31 Weissmann G, Spilberg I. Breakdown of cartilage proteinpolysaccharide by lysosomes. Arthritis Rheum 1968; 9: 162-9.

32 Janoff A, Feinstein G, Malemud C J, Elias J M. Degradation of cartilage proteoglycan by human leukocyte granule neutral proteases - a model of joint injury. J Clin Invest 1976; 57: 615-24.

${ }^{33}$ Keiser H, Greenwald R A, Feinstein G, Janoff A. Degradation of cartilage proteoglycan by human leukocyte granule neutral proteases-a model of joint injury. J Clin Invest 1976; 57: 625-32.

34 Barrett A J, Starkey P M. The possible role of leucocyte proteinases in the tissue damage of rheumatoid arthritis. In: Gordon J L, Hazleman B L, eds. Rheumatoid Arthritis. Amsterdam: Elsevier/North-Holland Biomedical Press, 1977: 211-9.

35 Murphy G, Reynolds J J, Bretz U, Baggiolini M. Collagenase is a component of the specific granules of human neutrophil leucocytes. Biochem J 1977; 162: 195-7.

36 Mohr W, Menninger H. Polymorphonuclear granulocytes at the pannus-cartilage junction in rheumatoid arthritis. Arthritis Rheum in press.

37 Mohr W, Wessinghage D, Köhler G. Neutrophile Granulozyten bei der rheumatischen Gewebsdestruktion. I. Lichtmikroskopischer Nachweis neutrophiler Granulozyten in Rheumaknoten. $Z$ Rheumatol 1980; 39: 322-30.

38 Mohr W, Köhler G, Wessinghage D. Polymorphonuclear granulocytes in rheumatic tissue destruction. II. Demonstration of PMNs in rheumatoid nodules by electron microscopy. In preparation.

39 Woolley D E, Harris E D, Mainardi C L, Brinckerhoff C E. Collagenase immunolocalization in cultures of rheumatoid synovial cells. Science $1978 ; 200$ : 773-5.

40 Woolley D, Brinckerhoff C E, Mainardi C L, Vater C A, Evanson J M, Harris E D. Collagenase production by rheumatoid synovial cells: morphological and immunohistochemical studies of the dendritic cell. Ann Rheum Dis 1979; 38: 262-70. 